\title{
Wombstone-massive calcified fibroid: a case report
}

\section{Shruthi Ananthula, Ushadevi Gopalan*}

\begin{abstract}
Department of Obstetrics and Gynecology, Shri Sathya Sai Medical College and Research Institute, Ammapettai, Tamil
\end{abstract} Nadu, India

Received: 17 January 2021

Accepted: 11 February 2021

\section{*Correspondence:}

Dr. Ushadevi Gopalan,

E-mail: ushag7@hotmail.com

Copyright: () the author(s), publisher and licensee Medip Academy. This is an open-access article distributed under the terms of the Creative Commons Attribution Non-Commercial License, which permits unrestricted non-commercial use, distribution, and reproduction in any medium, provided the original work is properly cited.

\begin{abstract}
We report a case of a calcified submucous leiomyoma in 50 years women with lower abdominal discomfort. She had no previous history of surgery. Work up confirmed a calcified leiomyoma. The diagnosis was made by radiological findings. Total abdominal hysterectomy with bilateral salpingo-oophorectomy is the surgery of choice for these cases. Histopathological examination confirmed a calcified leiomyoma. A calcified leiomyoma in a post-menopausal woman is rare.
\end{abstract}

Keywords: Calcified leiomyoma, Fibroid, Postmenopausal

\section{INTRODUCTION}

Among women of reproductive age group most common tumors are uterine leiomyomas which are benign in nature. ${ }^{1}$ They present with various degenerations which can be confirmed on histopathological examination like hyaline, cystic, red, fatty and calcified degeneration. Usually in 70-90\% of women shrinkage of fibroid occurs after menopause and only a very few cases of postmenopausal calcified fibroids have been reported in literature. ${ }^{1-3}$ However in a post-menopausal women leiomyoma forming a bony hard mass is a rare phenomenon. ${ }^{4}$ Here we are presenting a rare case of huge calcified fibroid which occurred in a post-menopausal woman where total abdominal hysterectomy and bilateral salpingo-ophorectomy was done to manage this case.

\section{CASE REPORT}

A 50 years old woman who attained menopause 5 years back presented to our outpatient department with pain in the lower abdomen since two months. Who had a history of two full-term normal vaginal deliveries, underwent sterilization 25 years back after her last child-birth. This patient did not have any irregular menstrual cycles, no history of intake of hormone replacement therapy or oral combined pills. General physical examination did not reveal any significant abnormality. Abdominal examination showed mass corresponding to 24 weeks size, firm, regular, non-tender. Pervaginal examination revealed uterus of size corresponding to 24 weeks, firm in consistency, fornices free. On abdominal ultrasound, there was a solid heteroechoeic lesion measuring $10 \times 6 \mathrm{~cm}$ in the anterior myometrium and fundal region. MRI done revealed heterointense round oval lesion of size $10 \times 13 \times 12$ $\mathrm{cm}$ in the fundal region of uterus with calcifications. Total abdominal hysterectomy with bilateral salpingooopherectomy was done for this patient. All biochemical and hematological examinations were within normal limits. Intra-operative period was uneventful except that there was difficulty in extracting the uterus through the pfannsteil incision given as the fibroid was rock hard with no flexibility. Postoperatively there were no complications and the specimen was sent to histopathological examination.

On gross examination, the uterus with fibroid measured $10 \times 12 \mathrm{~cm}$. The mass had a bony hard feeling during cutting with a saw. Cut section was solid whitish with irregular whorled pattern and showed clusters and 
fascicles of smooth muscle nests with extensive calcification all over the section.

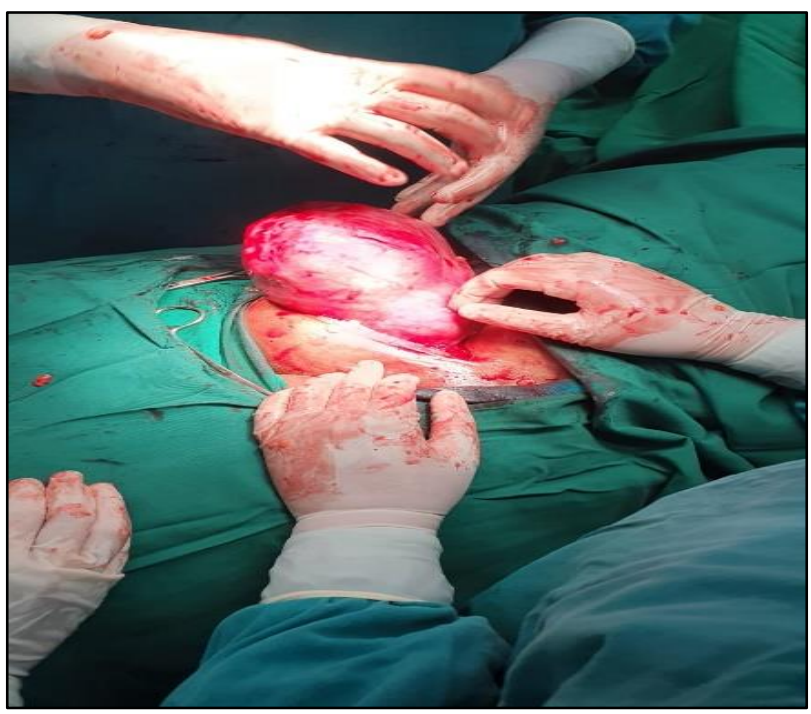

Figure 1: Intra operative picture showing uterus with massive fibroid.

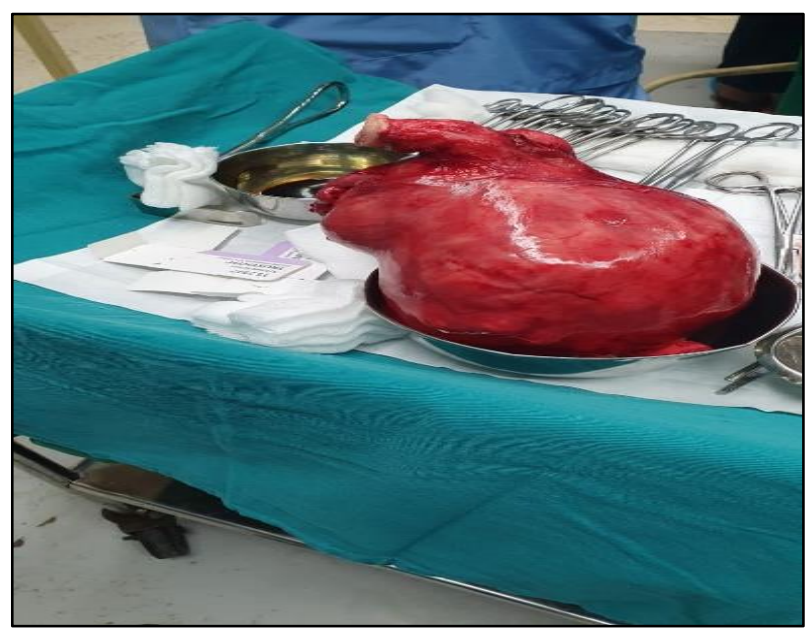

Figure 2: Gross specimen of uterus with myoma.

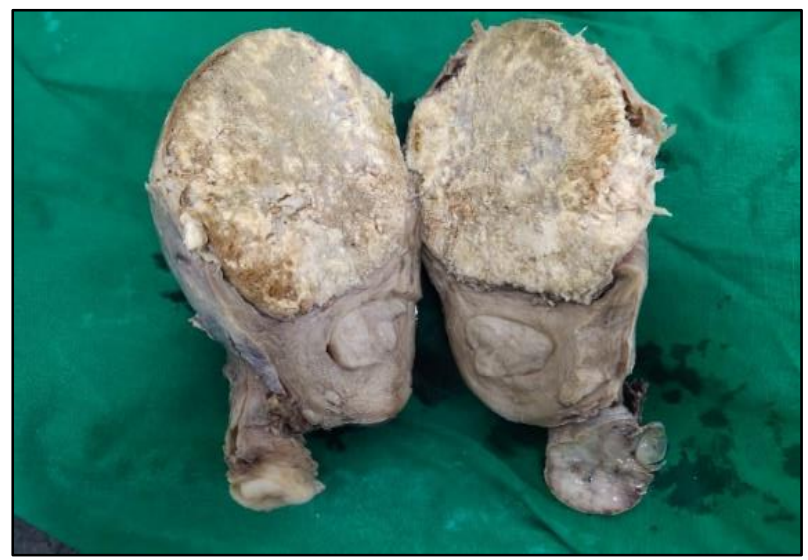

Figure 3: Cut section of uterus with calcified leiomyoma.

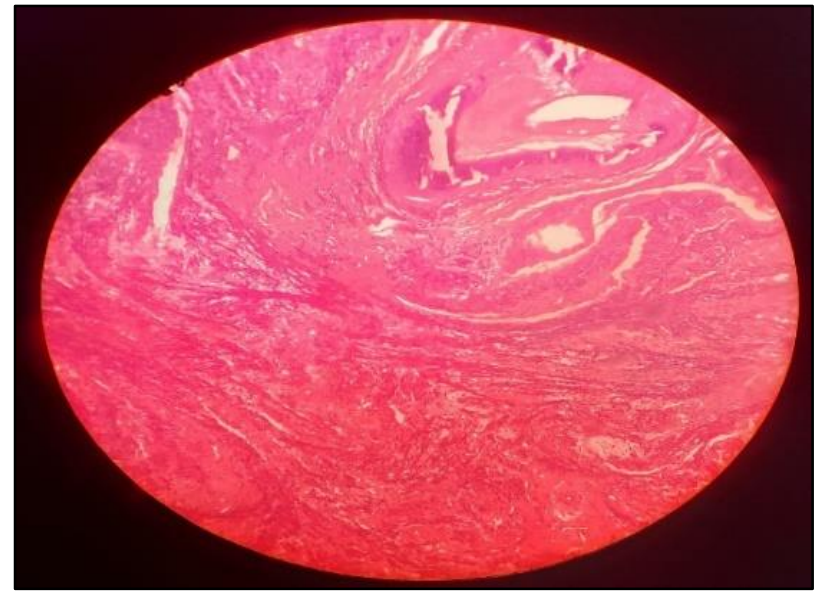

Figure 4: Histomorphology of calcified leiomyoma with deep basophilic staining granular deposition over the tissue section and benign spindle cells in bundles,

fascicles, and whorled pattern of smooth muscle.

On light microscopy there were basophilic granular deposits which indicates calcification. Atrophic endometrium with chronic nonspecific cervicitis was present. Final diagnosis confirmed by histopathology was a calcified fibroid.

\section{DISCUSSION}

Uterine leiomyomas are benign tumors, which occur mostly in women more than 35 years of age, around 20$30 \%$ of these women present with clinical manifestations. ${ }^{5}$ The main component of these tumors is smooth muscle along with varying amounts of fibrous connective tissue. Most of the fibroids usually regress after menopause, but there are a few cases that have reported growth of fibroid after menopause. ${ }^{6}$

They present with symptoms like irregular menstrual cycles with menorrhagia, lower abdominal, pelvic pain, pressure symptoms of bladder and bowel. In our case patient had no complaints of myoma related symptoms except pain. These tumors occurring in post-menopausal women is rare, as their growth is thought to be estrogen dependent, so it is difficult to predict the symptoms and clinical findings in these women. However, growth factors, such as (IGF) insulin like growth factor or (EGF) epidermal growth factor, might play a role in growth of myomas post-menopausally. There might also be an association of fibroids with polypeptide growth factors like transforming growth factors, (PDGF) platelet derived growth factor and (VEGF) vascular growth factor, which restore the growth even in cases of decreased estrogen. Many of these growth factors are overexpressed and increase DNA synthesis or proliferation of smooth muscle cells and also promote angiogenesis or mitogenesis. ${ }^{7}$ If in case a post-menopausal women is obese, there is usually conversion of adrenal derived androstenedione to estrone peripherally by aromatization of fat which also might play a role in growth of these leiomyomas. As these fibroids 
grow in size they outgrow their blood supply, resulting in various types of degenerations. Overtime, there is decreased blood supply within the myoma which results in ischemia and calcium is usually deposited at the periphery, but in our case as the degenerative changes progressed the fibroid became solidly calcified entirely.

\section{CONCLUSION}

Calcified fibroid is a rare finding in women after attaining menopause. It often leads to a diagnostic difficulty. Hysterectomy is management of choice in these cases and post-operative histopathological examination of the tumor can give a confirmed diagnosis.

Funding: No funding sources Conflict of interest: None declared

Ethical approval: Not required

\section{REFERENCES}

1. Singh K, Prasad D, Pankaj S, Suman S, Kumar A, Choudhary V, et al. Postmenopausal massive subserous calcified fibroid - A case report. J Evol Med Dent Sci. 2014;3:2255-7.

2. Samal SK, Rathod S, Reddi R, Anandraj R. An unusual presentation of a severely calcified subserous leiomyoma in a postmenopausal woman: a case report. Int J Reprod Contracept Obstet Gynecol. 2014;3:463-5.

3. Hwang JH, Modi GV, Lee JK. An unusual presentation of a severely calcified parasitic leiomyoma in a postmenopausal woman. J Soc Laparoendoscop Surg. 2010;14(2):299-302.

4. Ozdemır O, Atalay CR, Sarı ME, Sen E, Nebıglu M. Postmenopausal calcified pedunculated large subserous leiomyoma: A case report. Obstet Gynecol Cases Rev. 2015;2:54.

5. Szk laruK J, Tamm EP, Choi H, Varavithya V. MR imaging of common and uncommon large mass. Radiographics.2003;23:403-424.

6. Rajab KE, Aradi AN, Datta BN. Postmenopausal leiomyomatosis peritonealis disseminata. Int $\mathbf{J}$ Gynecol Obstet. 2000;68:271-2.

7. Flake GP, Andersen J, Dixon. Etiology and pathogenesis of uterine leiomyomas: a Environ Health perspect. 2003;111:1037-1054.

Cite this article as: Ananthula S, Gopalan U. Wombstone-massive calcified fibroid: a case report. Int J Reprod Contracept Obstet Gynecol 2021;10:1701-3. 